\title{
Ketone-Body Production and Oxidation in Fasting
}

\section{Obese Humans}

\author{
G. A. Reichard, Jr., O. E. Owen, A. C. Haff, P. Paul, and W. M. Bortz \\ From the Division of Research, Lankenau Hospital, Philadelphia, Pennsylvania \\ 19151, and the Department of Medicine and the General Clinical Research \\ Center, Temple University Health Sciences Center, \\ Philadelphia, Pennsylvania 19140
}

A в S T R A C T Rates of plasma acetoacetate and total ketone-body production and oxidation to $\mathrm{CO}_{2}$ were determined by an isotope tracer technique in eight obese subjects undergoing progressive starvation. After a brief fast and under conditions of mild ketonemia and minimal ketonuria, rates of acetoacetate and total ketone-body production and oxidation were directly related to the increasing plasma concentration. After a longer fast and with severer ketonemia, acetoacetate and total ketone-body production and oxidation rates were higher but became constant and unrelated to the plasma concentrations. The maximum rates of total ketone-body production and oxidation were about $150 \mathrm{~g} / 24 \mathrm{~h}$ and $129 \mathrm{~g} / 24 \mathrm{~h}$, respectively.

Although an increased ketone-body production was the primary factor responsible for the hyperketonemia, an imbalance between production and removal of the ketone bodies cannot be excluded. Such an imbalance could account, at least in part, for the developing hyperketonemia and for the lack of relationship between production rates and plasma concentrations.

\section{INTRODUCTION}

Starvation-induced hyperketonemia may result from an increased production or a decreased removal of the ketone bodies or a combination of these processes. Whereas an imbalance between rates of ketone body production and removal has been suggested as the cause of ketosis in fasting animals (1-4), similar information is not available in the human. Furthermore, no direct attempts have been made in humans to measure rates of ketone-body oxidation and their contribution to total body caloric economy, although these compounds have

Received for publication 4 May 1973 and in revised form 5 October 1973. been shown to be important fuels for specific tissues during starvation $(5,6)$.

In this study ketone-body production and oxidation rates were determined simultaneously in fasting humans with varying plasma acetoacetate (AcAc) ${ }^{1}$ and $\beta$-hydroxybutyrate $(\beta-\mathrm{OHB})$ concentrations by an isotope tracer technique.

\section{METHODS}

Subjects. Eight obese volunteers, initially weighing from 82 to $175 \%$ above ideal body weight, were selected for admission to the Clinical Research Unit of Lankenau Hospital (Table I). Before admission, the purpose and potential risks of the procedure were discussed with each subject, and informed consent was obtained. All subjects had normal hemograms, urinalyses, serum thyroxine concentrations, electrocardiograms, and chest radiographs. In addition, sequential multiple analyzer $12 / 60$ profiles (total protein, albumin, calcium, inorganic phosphorus, total bilirubin, uric acid, cholesterol, glucose, urea nitrogen, alkaline phosphatase, lactic dehydrogenase, and glutamic oxaloacetate transaminase) were normal in all subjects except $\mathrm{E}$. $\mathrm{K}$, who was a known diabetic patient at the time of admission and had fasting hyperglycemia. Her oral hypoglycemic drug was withheld during starvation.

During the 2-24 day starvation period, daily intake consisted of one multivitamin capsule (Unicap, Upjohn Co., Kalamazoo, Mich.) and at least $1,500 \mathrm{ml}$ of water.

Preparation of $\left[3-{ }^{14} C\right] A c A c$. Previous experience in our laboratory had shown that $0.5 \mathrm{M}$ sodium AcAc ( $\mathrm{NaAcAc}$ ), $\mathrm{pH} 7.4$, when frozen and stored at $-4^{\circ} \mathrm{C}$, is stable for periods of at least several months. This concentration was chosen for the primary $\left[{ }^{14} \mathrm{C}\right] \mathrm{AcAc}$ solution. It was prepared from $\left[3-{ }^{14} \mathrm{C}\right]$ ethyl AcAc (Amersham/Searle Corp., Arlington Heights, Ill.) to which had been added freshly redistilled carrier. After hydrolysis for $1.5 \mathrm{~h}$ in a slight excess of $1.0 \mathrm{~N} \mathrm{NaOH}$, the solution was adjusted to $\mathrm{pH}$ 7.4 with $1.0 \mathrm{~N} \mathrm{HCl}$ and lyophilized. Distilled water was added to yield a concentration of about $0.5 \mathrm{M} \mathrm{NaAcAc}$,

${ }^{1}$ Abbreviations used in this paper: AcAc, acetoacetate; $\beta$-OHB, $\beta$-hydroxybutyrate; FFA, free fatty acids. 
TABLE I

Clinical Data

\begin{tabular}{lccccl}
\hline Subject & Age & Sex & Height & $\begin{array}{c}\text { Weight on } \\
\text { day of } \\
\text { study }\end{array}$ & \multicolumn{1}{c}{ Diagnosis } \\
\hline R. K. & $y r$ & & $c m$ & $k g$ & \\
D. D. & 49 & F & 158.1 & 140.0 & Obesity \\
E. K. & 56 & F & 151.1 & 88.6 & Obesity \\
S. W. & 70 & F & 147.2 & 98.6 & Obesity, diabetes mellitus \\
F. R. & 37 & M & 171.5 & 138.2 & Obesity \\
E. Z. & 40 & F & 169.0 & $109.8,102.0^{*}$ & Obesity \\
P. F. & 54 & F & 153.7 & 82.4 & Obesity \\
M. H. & 35 & F & 163.2 & 97.3 & Obesity \\
\hline
\end{tabular}

* Subject F. R. was studied at 3 and 24 days of fast.

and the resulting clear solution was sterilized by passage through a $0.22 \mu \mathrm{m}$ Swinnex filter unit (Millipore Corp., Bedford, Mass.). Sterility was established by the absence of growth after $72 \mathrm{~h}$ in appropriate culture media. Such sterile solutions were stored frozen in sealed vials. Before freezing, aliquots were aseptically removed and analyzed for AcAc concentration by enzymatic techniques and for radiochemical purity by distillation of acetone and formation of the Denigès' salt as described below.

Methods of infusion and collections of blood, urine, and expired gases. On the day of the study the subject was at rest on a bed in a special room equipped with an efficient ventilation system to exhaust exhaled ${ }^{14} \mathrm{CO}_{2}$ and to maintain normal room air gas content. The subject voided before the study, and urine was collected throughout and at the close of the experimental period. Under local anesthesia a catheter was placed percutaneously in a peripheral artery for collecting blood samples. An antecubital venous catheter was inserted for the ${ }^{14} \mathrm{C}$ tracer infusion.

Immediately before use the primary $\left[{ }^{14} \mathrm{C}\right] \mathrm{AcAc}$ solution was thawed and an appropriate aliquot containing 100-150 $\mu \mathrm{Ci}(1-3 \mathrm{ml})$ was diluted to $100 \mathrm{ml}$ with sterile isotonic saline. The specific activity of the tracer ranged from 1-2 $\mu \mathrm{Ci} / \mathrm{mg}$ and had a radiochemical purity of at least $97 \%$. Throughout the infusion period the syringe on the motordriven pump was encased in a coiled tube and cooled by circulating ice-cold water. Samples of the infusate were assayed for radioactivity before and after the infusion period. A priming dose of about $10 \mu \mathrm{Ci}$ was given, followed by an infusion of $0.2 \mu \mathrm{Ci} / \mathrm{min}(0.15 \mathrm{ml} / \mathrm{min}$.) for $6-8 \mathrm{~h}$. This ratio of priming dose to infusion rate was selected after preliminary studies showed that a constant specific activity was rapidly attained. About $50-150 \mathrm{mg}$ of radioactive tracer was given throughout the infusion period.

At hourly intervals blood samples were collected in glass syringes moistened with heparin. Plasma was mixed with an equal volume of chilled perchloric acid $(30 \% \mathrm{wt} /$ vol) and centrifuged at $4^{\circ} \mathrm{C}$. The supernatant fluid was neutralized with $20 \% \mathrm{KOH}$, allowed to stand in ice for $30 \mathrm{~min}$, and centrifuged again. Samples of the supernate were immediately removed for determination of AcAc and $\beta$-OHB by enzymatic techniques (7).

The remaining supernate was divided, and the radioactivity in AcAc and total ketone bodies was determined by modifications of the method of Bates, Krebs, and Wil- liamson (1). For determination of $\left[{ }^{14} \mathrm{C}\right] \mathrm{AcAc}$, acetone was distilled from a solution containing $1-2 \mathrm{ml}$ supernate, 30 $\mu \mathrm{mol}$ of carrier AcAc, and $2.0 \mathrm{ml}$ of $50 \% \mathrm{H}_{2} \mathrm{SO}_{4}$ in a final volume of $100 \mathrm{ml}$. The distillation was conducted in an all-glass apparatus, as described by Weichselbaum and Somogyi (8), at a rate of about $1 \mathrm{ml}$ distillate/min for 15 min. The distillate was collected in tared screw-capped centrifuge tubes cooled in a crushed ice-water mixture and $6 \mathrm{ml}$ of $10 \% \mathrm{HgSO}_{4}$ and $3 \mathrm{ml} 50 \% \mathrm{H}_{2} \mathrm{SO}_{4}$ were added. After the sealed tubes were heated for $45 \mathrm{~min}$ in a boiling water bath, the precipitate was washed with ice-cold water and finally with acetone, and dried in vacuo over silica gel. Numerous studies with standard solutions containing up to $100 \mu \mathrm{mol}$ AcAc showed complete recovery of acetone as the Denigès salt with a ratio of $1.16 \mathrm{mg}$ salt $/ \mu \mathrm{mol} \mathrm{AcAc}$ (acetone), a value almost exactly that originally reported by Van Slyke (9). Solutions treated in a similar manner and containing at least $100 \mu \mathrm{mol} \mathrm{DL}-\beta$-OHB never yielded a Denigès precipitate.

The Denigès precipitate, usually $34-35 \mathrm{mg}$, was transferred to counting vials and suspended in $15 \mathrm{ml}$ of scintillation counting mixture composed of $5 \mathrm{~g}$ of 2.5-diphenyloxazole, $0.3 \mathrm{~g}$ of 2.2-p-phenylene bis-5-phenyloxazole and $25 \mathrm{~g}$ of Thixcin (The Baker Castor Oil Co., Bayonne, N. J.) in 1 liter of toluene.

For determination of radioactivity in total ketone bodies, $\beta$-OHB was enzymatically converted to AcAc, carrier AcAc was added, and the distillation and counting procedures repeated. In order to accomplish the enzymatic conversion, a reaction mixture similar to that employed by McGarry, Guest, and Foster (10) was used. A mixture containing $1,500 \mu \mathrm{mol}$ Tris buffer, $\mathrm{pH} 9.3,12 \mu \mathrm{mol} \mathrm{N^{ \prime }}{ }^{+}$, and $20 \mu 1$ of $\beta$-OHB dehydrogenase, $15 \mathrm{U} / \mathrm{ml}$ (Boehringer Mannheim Corp., New York) in a final volume of $3 \mathrm{ml}$ was used. This system was found to stoichiometrically convert 0.5 $\mu \mathrm{mol}$ of $\beta-\mathrm{OHB}$ to $\mathrm{AcAc}$ in $1 \mathrm{~h}$ and was used when concentrations of $\beta$-OHB up to $0.5 \mu \mathrm{mol} / \mathrm{ml}$ of supernate were found. At higher concentrations, encountered in the subjects fasted for long periods of time, appropriate modifications in the reaction mixture were made so that at least $1 \mathrm{ml}$ of supernate was always used, and the quantity of radioactive material taken for assay was not compromised. In practice, the reaction was accomplished in a $300-\mathrm{ml}$ round-bottom flask at room temperature for $2.5 \mathrm{~h}$. Thereafter, $30 \mu \mathrm{mol}$ of carrier AcAc, $2.0 \mathrm{ml}$ of $50 \% \mathrm{H}_{2} \mathrm{SO}_{4}$, and sufficient distilled water to make a final volume of 100 
$\mathrm{ml}$ were added and the flask was connected to the distillation apparatus.

Aqueous and plasma standards containing known amounts of $\left[3-{ }^{14} \mathrm{C}\right] \mathrm{AcAc}$ and $\left[3-{ }^{14} \mathrm{C}\right] \beta-\mathrm{OHB}$ (as the DL mixture) were subjected to the complete procedure and 98-102\% of added radioactive $\mathrm{AcAc}$ and $\mathrm{D}(-)-\beta-\mathrm{OHB}$ was recovered from all studies.

Respiratory gas samples were obtained simultaneously with each blood sample. The gas samples were analyzed for $\mathrm{O}_{2}, \mathrm{CO}_{2}$, and ${ }^{14} \mathrm{CO}_{2}$ content as previously described (11).

Aliquots of pooled urine were assayed for AcAc and $\beta$-OHB by enzymatic techniques (7), for total radioactivity by counting in Bray's solution (12), and for radioactivity in AcAc and total ketone bodies by the procedure described for plasma.

During the infusion period in each study periodic blood samples were obtained and analyzed for glucose (13) and free fatty acids (FFA) (14). In the latter assay, a double extraction technique was used to avoid interference due to high concentrations of plasma ketone bodies.

Calculations. The rate of AcAc production was calculated from the infusion rate of the tracer and the mean specific activity of plasma AcAc by the equation:

$$
\text { Rate of production }=\frac{\text { infusion rate }(\mathrm{n} \mathrm{Ci} / \mathrm{min})}{\text { specific activity }(\mathrm{n} \mathrm{Ci} / \mu \mathrm{mol})}
$$

The AcAc production rate represents an underestimation of the total ketone-body production to the extent that isotopic equilibration between $\mathrm{AcAc}$ and $\beta-\mathrm{OHB}$ does not occur. Therefore, the rate of total ketone-body production was calculated from the infusion rate of the tracer and the mean specific activity of the total plasma ketone bodies, as suggested by McGarry et al. (10).

Under steady state conditions and during the continuous infusion of a tracer, the specific activity of exhaled $\mathrm{CO}_{2}$ and the ${ }^{14} \mathrm{CO}_{2}$ output rose in the form of an exponential curve that asymptotically approaches a constant value. The rise is due to a slow exchange between the ${ }^{14} \mathrm{CO}_{2}$ derived from oxidation of the infused tracer and the unlabeled bicarbonate pool. The constant value represents the ideal situation in which the exhaled $\mathrm{CO}_{2}$ and the bicarbonate pool have the same specific activity as the $\mathrm{CO}_{2}$ arising from tissue oxidation. During the continuous infusion of $\left[{ }^{14} \mathrm{C}\right]-$ bicarbonate a similar pattern of behavior in the specific activity of exhaled $\mathrm{CO}_{2}$ has been observed in animals (15) and humans (11). In the human studies, the asymptotic value of $\mathrm{CO}_{2}$ specific activity was reached after $480 \mathrm{~min}$ of continuous infusion. After this time the specific activity of exhaled $\mathrm{CO}_{2}$ was reasonably constant and the recovery of ${ }^{14} \mathrm{CO}_{2}$ in exhaled air was $80 \%$ of that administered during any given infusion period. The incomplete recovery was probably due to the presence of bicarbonate pools that turn over very slowly, i.e. bone (15), and to incorporation of ${ }^{14} \mathrm{CO}_{2}$ into other compounds, i.e. urea (16). It is reasonable to assume that ${ }^{14} \mathrm{CO}_{2}$ derived from the oxidation of other tracers would be recovered at a rate no greater than that observed for $\left[{ }^{14} \mathrm{C}\right]$ bicarbonate. On the basis of the known recovery of ${ }^{14} \mathrm{CO}_{2}$ during the continuous infusion of $\left[{ }^{14} \mathrm{C}\right]$ bicarbonate it is possible to derive an equation whereby the recovery of ${ }^{14} \mathrm{CO}_{2}$ and the specific activity of $\mathrm{CO}_{2}$ at any time during the infusion of a tracer may be corrected. The methods and equations necessary to do this were originally described by Steele, Altszuler, Wall, Dunn, and de Bodo (15) and previously applied to studies of free fatty acids, glucose, and glycerol metabolism in man (11, $17,18)$. For these latter studies an equation describing the recovery of ${ }^{14} \mathrm{CO}_{2}$ in humans fasted for $12-14 \mathrm{~h}$ was provided by Issekutz, Paul, Miller, and Bortz (11). More recently, we have extended these studies to include a group of obese subjects who fasted overnight and for periods of 20-35 days. Despite the appearance of metabolic acidosis in the subjects, no major differences in the rate of appearance of ${ }^{14} \mathrm{CO}_{2}$ in exhaled air were noted after administration of $\left[{ }^{14} \mathrm{C}\right]$ bicarbonate (unpublished data). Thus, the percent of $\mathrm{CO}_{2}$ derived from the oxidation of plasma $\mathrm{AcAc}$ and the rate of oxidation of plasma AcAc were calculated by the usual procedures (11). With the same methods of calculation, but based on the mean specific activity of plasma total ketone bodies, the percent of $\mathrm{CO}_{2}$ derived from the oxidation of plasma total ketone bodies and the rate of oxidation of plasma total ketone bodies were also estimated.

TABLE II

Arterial Concentration of Metabolites

\begin{tabular}{|c|c|c|c|c|c|c|}
\hline \multirow[b]{2}{*}{ Subject } & \multirow{2}{*}{$\begin{array}{l}\text { Days of } \\
\text { fast }\end{array}$} & \multicolumn{3}{|c|}{ Plasma } & \multirow{2}{*}{$\begin{array}{l}\text { Plasma } \\
\text { FFA } \ddagger\end{array}$} & \multirow{2}{*}{$\begin{array}{l}\text { Blood } \\
\text { glucose }\end{array}$} \\
\hline & & AcAc* & $\beta \mathrm{OHB} *$ & Total $*$ & & \\
\hline & & $\mu \mathrm{mol} / \mathrm{ml}$ & $\mu \mathrm{mol} / \mathrm{ml}$ & $\mu \mathrm{mol} / \mathrm{ml}$ & $\mu m o l / m l$ & $\mu \mathrm{mol} / \mathrm{ml}$ \\
\hline R. K. & 2 & $0.33 \pm 0.01$ & $0.64 \pm 0.04$ & $0.97 \pm 0.05$ & 0.94 & 4.8 \\
\hline D. D. & 3 & $0.66 \pm 0.01$ & $0.81 \pm 0.04$ & $1.47 \pm 0.03$ & 0.93 & 4.2 \\
\hline E. K. & 3 & $1.21 \pm 0.02$ & $2.51 \pm 0.12$ & $3.72 \pm 0.14$ & 1.02 & 9.9 \\
\hline S. W. & 3 & $0.94 \pm 0.02$ & $2.27 \pm 0.16$ & $3.21 \pm 0.16$ & 1.19 & 3.2 \\
\hline F. R.-1 & 3 & $0.67 \pm 0.03$ & $1.59 \pm 0.07$ & $2.26 \pm 0.09$ & 1.04 & 4.4 \\
\hline F. R.-2 & 24 & $1.46 \pm 0.03$ & $5.78 \pm 0.03$ & $7.24 \pm 0.21$ & 1.14 & 3.7 \\
\hline E. Z. & 17 & $1.81 \pm 0.04$ & $7.88 \pm 0.29$ & $9.70 \pm 0.32$ & - & - \\
\hline P. F. & 24 & $1.67 \pm 0.03$ & $5.60 \pm 0.17$ & $7.27 \pm 0.17$ & 1.04 & 3.8 \\
\hline M. H. & 24 & $1.43 \pm 0.01$ & $2.52 \pm 0.09$ & $3.95 \pm 0.09$ & 1.29 & 3.7 \\
\hline
\end{tabular}

* Mean \pm SEM of six to eight values obtained during the infusion period.

$\ddagger$ Mean of two to four values obtained during the infusion period. 
TABLE III

Ketone Body Production and Oxidation

\begin{tabular}{|c|c|c|c|c|c|c|c|c|}
\hline \multirow[b]{2}{*}{ Subject } & \multicolumn{2}{|c|}{ AcAc } & \multirow[b]{2}{*}{$\begin{array}{c}\text { AcAc } \\
\text { oxidized }\end{array}$} & \multirow{2}{*}{$\begin{array}{l}\mathrm{CO}_{2} \\
\text { from } \\
\mathrm{AcAc}\end{array}$} & \multicolumn{2}{|c|}{ Total ketone-body } & \multirow[b]{2}{*}{$\begin{array}{c}\text { TKB* } \\
\text { oxidized }\end{array}$} & \multirow{2}{*}{$\begin{array}{c}\mathrm{CO}_{2} \\
\text { from } \\
\text { TKB }^{*}\end{array}$} \\
\hline & $\begin{array}{l}\text { Produc- } \\
\text { tion }\end{array}$ & $\begin{array}{c}\text { Oxida- } \\
\text { tion }\end{array}$ & & & $\begin{array}{l}\text { Produc- } \\
\text { tion }\end{array}$ & $\begin{array}{c}\text { Oxida- } \\
\text { tion }\end{array}$ & & \\
\hline & \multicolumn{2}{|c|}{$\mu \mathrm{mol} / \mathrm{kg} / \mathrm{min}$} & $\%$ & $\%$ & \multicolumn{2}{|c|}{$\mu \mathrm{mol} / \mathrm{kg} / \mathrm{min}$} & $\%$ & $\%$ \\
\hline \multicolumn{9}{|c|}{$2-3$ day fast } \\
\hline R. K. & 3.14 & 2.76 & 87.9 & 17.8 & 5.72 & 4.85 & 84.7 & 31.3 \\
\hline D. D. & 5.49 & 5.86 & 106.8 & 25.6 & 7.57 & 8.20 & 108.2 & 35.8 \\
\hline E. K. & 6.82 & 4.95 & 72.5 & 28.5 & 9.31 & 6.71 & 72.1 & 38.7 \\
\hline S. W. & 6.70 & 6.26 & 93.5 & 26.7 & 11.25 & 10.30 & 91.5 & 44.0 \\
\hline F. R.-1 & 5.05 & 5.32 & 105.4 & 21.8 & 8.82 & 9.36 & 106.0 & 36.6 \\
\hline \multicolumn{9}{|c|}{$17-24$ day fast } \\
\hline F. R.-2 & 6.81 & 5.69 & 83.6 & 28.0 & 11.90 & 9.75 & 82.1 & 48.0 \\
\hline E. Z. & 8.05 & 6.10 & 75.8 & 32.1 & 10.35 & 7.88 & 76.3 & 41.2 \\
\hline P. F. & 7.15 & 6.35 & 88.8 & 30.7 & 10.63 & 9.55 & 89.8 & 46.1 \\
\hline M. H. & 7.75 & 6.86 & 88.5 & 30.0 & 10.07 & 8.96 & 89.0 & 39.2 \\
\hline
\end{tabular}

* TKB, Total Ketone Bodies

\section{RESULTS}

Arterial concentration of metabolities. In Table II the mean arterial metabolite concentrations in each subject during the $\left[{ }^{14} \mathrm{C}\right] \mathrm{AcAc} \cdot$ infusion period are shown. One subject (F. R.) was studied after 3 and 24 days of fast. The blood glucose concentration of the known diabetic subject (E. K.) was $9.9 \mu \mathrm{mol} / \mathrm{ml}(178 \mathrm{mg} /$ $100 \mathrm{ml}$ ) despite a 3-day fast. After the 2-3-day fast, plasma ketone-body concentrations showed considerable subject-to-subject variations.

Specific activity of plasma ketone bodies and respiratory $\mathrm{CO}_{2}$. Time course changes in the specific activity of plasma AcAc, $\beta-\mathrm{OHB}$, total ketone bodies, and respiratory $\mathrm{CO}_{2}$ during an 8 -h infusion of $\left[{ }^{14} \mathrm{C}\right] \mathrm{AcAc}$ in a 3-day fasted subject (D. D.) are shown in Fig. 1. Throughout the infusion period the specific activity of AcAc, $\beta-\mathrm{OHB}$, and total ketone bodies remained reasonably constant while that of the respiratory $\mathrm{CO}_{2}$ rose, at first linearly, and then at a gradually decreasing rate. In each subject there was a rapid appearance of $\left[{ }^{14} \mathrm{C}\right] \beta$ $\mathrm{OHB}$ in plasma during the infusion of $\left[{ }^{14} \mathrm{C}\right] \mathrm{AcAc}$. The specific activities of the ketone bodies never became equal, although a constant and maximal ratio usually occurred within $1 \mathrm{~h}$ after the start of the infusion. The specific activity of $\beta-\mathrm{OHB}$ ranged from $35-72 \%$ that of AcAc in the nine studies performed. Generally, the higher ratios were found in the subjects with higher plasma ketone-body concentrations.

AcAc production and oxidation rates. AcAc production and oxidation rates are shown in Table III, and are plotted against the plasma concentration in Fig. 2. Although the data are limited, the plasma AcAc concentration appeared to be an exponential function of
AcAc production. In the subjects fasted for 2-3 days, excluding the diabetic subject $\mathrm{E}$. $\mathrm{K}$., the fraction of the AcAc produced that was immediately oxidized averaged $98.4 \pm 4.6 \%$ while in those fasted for 17-24 days, the average was $84.2 \pm 3.0 \%$. This decrease was significant $(P<0.05)$. The maximum rate of AcAc oxidation was about $6 \mu \mathrm{mol} / \mathrm{kg} / \mathrm{min}$ and was achieved at plasma concentrations of about $0.8 \mu \mathrm{mol} / \mathrm{ml}$. The percentage of respiratory $\mathrm{CO}_{2}$ derived from AcAc averaged $24.1 \%(17.8-28.5)$ in the subjects fasted for 2-3 days and $30.2 \%(28.0-32.1 \%)$ in those fasted for 1724 days.

Total ketone-body production and oxidation rates. Total ketone-body production and oxidation rates are listed in Table III and are plotted against the plasma concentration in Fig. 3. Fig. 3 reveals a direct relationship between plasma total ketone-body concentrations and production rates up to about $4 \mu \mathrm{mol} / \mathrm{ml}$, above which there was a constant total ketone-body production of about $11 \mu \mathrm{mol} / \mathrm{kg} / \mathrm{min}$. In the subjects fasted for $2-3$ days, excluding the diabetic subject $E$. K., the fraction of the total ketone-body production that was immediately oxidized averaged $97.6 \pm 5.7 \%$ while in those fasted for 17-24 days, the average was $84.3 \pm 3.2 \%$. The maximum rate of total ketone-body oxidation was about $9 \mu \mathrm{mol} /$ $\mathrm{kg} / \mathrm{min}$ and was achieved at a plasma concentration of about $4 \mu \mathrm{mol} / \mathrm{ml}$. The percentage of respiratory $\mathrm{CO}_{2}$ derived from total ketone-body oxidation averaged $37.3 \%$ $(31.3-44.0)$ in the subjects fasted for 2-3 days and $43.6 \%(39.2-48.0)$ in those fasted for 17-24 days.

Urinary excretion of ketone bodies. In these studies each subject voided immediately before and after the $\left[{ }^{14} \mathrm{C}\right] \mathrm{AcAc}$ infusion; residual bladder urine was not re- 

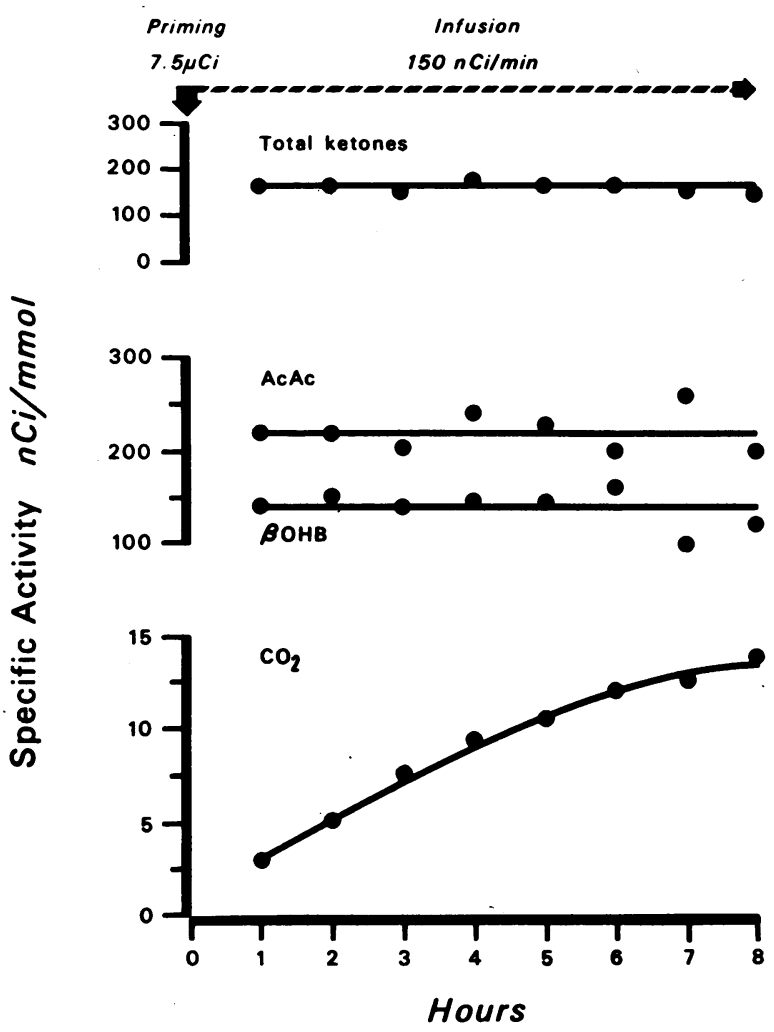

FIGURE 1 Time course changes in the specific activity of plasma ketone bodies and respiratory $\mathrm{CO}_{2}$. The priming dose and rate of infusion of $\left[{ }^{14} \mathrm{C}\right] \mathrm{AcAc}$ are shown at the top of the figure. The subject, D. D., had fasted for 3 days.

covered. From the subject fasted for 3 days and shown in Table IV, $1-2 \%$ of the infused radioactivity was recovered in urine during the infusion period while a somewhat higher recovery, 3-11\%, was found in those fasted for 24 days. As expected, the excretion of AcAc and $\beta-\mathrm{OHB}$, shown in the last two columns of the

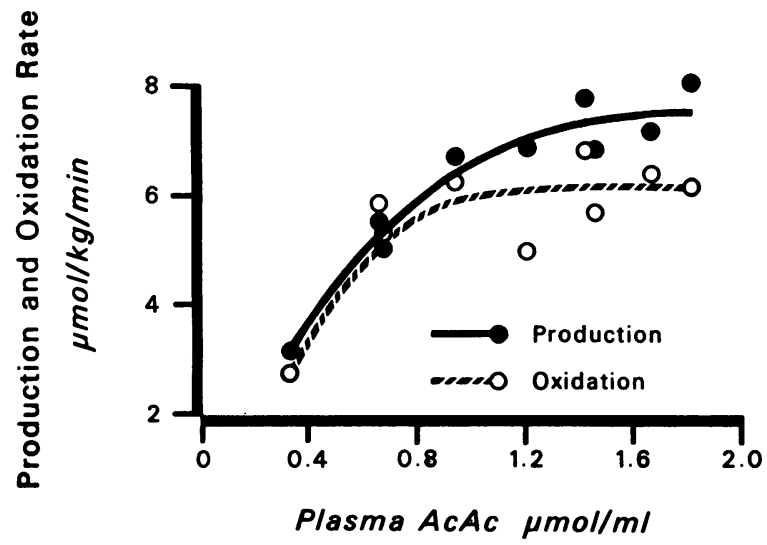

FIgURE 2 Relationship between AcAc production and oxidation rates and plasma concentrations. table, also increased with the longer fasts. After the 3 -day fast, urinary excretion rate was about $1-2 \%$ of the total ketone-body production rate. In the subjects fasted for 24 days the urinary excretion rate was about $3-13 \%$ of the total ketone-body production rate.

In all subjects the specific activity of plasma and urinary $\beta$-OHB were equal, indicating that urine $\beta-\mathrm{OHB}$ was directly derived from plasma. However, the specific activity of AcAc in urine was always lower than that in plasma. At least two explanations for this phenomenon are obvious. First, plasma $\beta-\mathrm{OHB}$, which was shown to have a specific activity somewhat lower than plasma AcAc, may have served as an important source of urine AcAc. Second, de novo synthesis of AcAc by renal tissue may have occurred. The specific activity of urine AcAc relative to that of plasma ranged from $0.23-0.71$, suggesting that $23-71 \%$ of AcAc appearing in urine may have arisen by simple diffusion from the plasma. The remainder, i.e. $29-77 \%$, would be derived from other sources. On this basis, and from the known rates of urinary AcAc excretion (Table IV), rates of renal AcAc production ranging from 0.01-0.2 $\mu \mathrm{mol} / \mathrm{kg} / \mathrm{min}$ may be calculated. The AcAc so produced and excreted in urine would not necessarily enter the plasma compartment and, therefore, would not be detected by the isotope method employed in these studies. The radioactivity in urine was found distributed in AcAc and $\beta$-OHB and also in an unknown form that was not precipitable as the Denigés salt. This fraction, which accounted for $30-80 \%$ of the total radioactivity present, may have been due to the small amount of impurity present in the administered tracer. Also, excretion of $\left[{ }^{14} \mathrm{C}\right]$ urea $(16)$ or bicarbonate cannot be excluded,

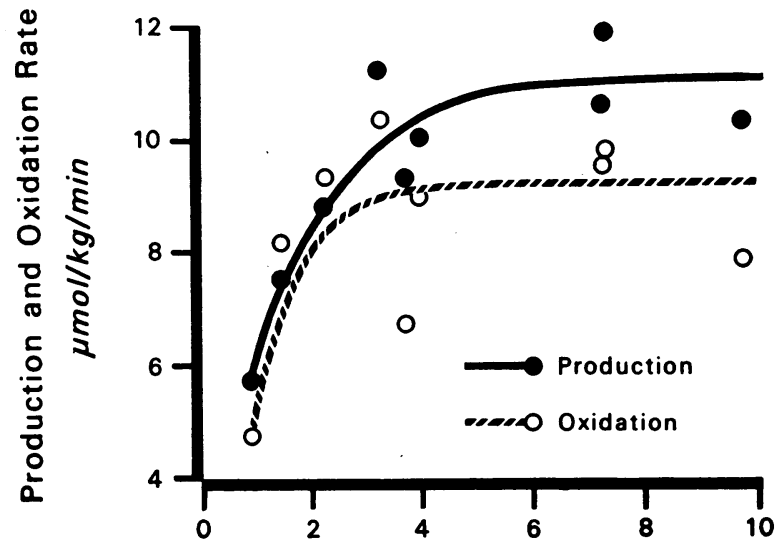

Total Plasma Ketone Bodies $\mu \mathrm{mol} / \mathrm{ml}$

Figure 3 Relationship between total ketone-body production and oxidation rates and plasma concentrations. 
TABLE IV

Urinary Excretion of Ketone Bodies

\begin{tabular}{|c|c|c|c|c|c|c|c|}
\hline \multirow[b]{2}{*}{ Subject } & \multirow{2}{*}{$\begin{array}{l}\text { Infused } \\
\text { radioactivity } \\
\text { excreted }\end{array}$} & \multicolumn{3}{|c|}{ Radioactivity in urine as } & \multirow{2}{*}{$\begin{array}{c}\text { Ratio of urine } \\
\text { AcAc sp. act. to } \\
\text { plasma AcAc sp. act. }\end{array}$} & \multicolumn{2}{|c|}{$\begin{array}{l}\text { Urinary } \\
\text { excretion }\end{array}$} \\
\hline & & AcAc & $\beta \mathrm{OHB}$ & Unknown & & AcAc & $\beta \mathrm{OHB}$ \\
\hline & $\%$ & \multicolumn{3}{|c|}{$\%$} & & \multicolumn{2}{|c|}{$\mathrm{mmol} / \mathrm{hr}$} \\
\hline \multicolumn{8}{|c|}{ 3-day fast } \\
\hline R. K. & 1.3 & 11.3 & 5.1 & 83.6 & 0.47 & 0.20 & 0.40 \\
\hline D. D. & 1.4 & 15.4 & 8.4 & 76.2 & 0.23 & 0.31 & 0.48 \\
\hline S. W. & 2.0 & 14.2 & 26.9 & 58.9 & 0.28 & 0.62 & 1.05 \\
\hline F. R.-1 & 1.1 & 21.3 & 22.6 & 56.0 & 0.26 & 0.34 & 0.46 \\
\hline \multicolumn{8}{|c|}{ 24-day fast } \\
\hline F. R.-2 & 10.1 & 14.8 & 50.6 & 34.6 & 0.34 & 1.77 & 4.95 \\
\hline P. F. & 10.6 & 21.8 & 47.4 & 30.8 & 0.51 & 1.95 & 6.50 \\
\hline M. H. & 3.3 & 25.8 & 29.6 & 44.6 & 0.71 & 0.63 & 1.15 \\
\hline
\end{tabular}

All studies were of 8-h duration except D. D. and F. R.-2, which were $7 \mathrm{~h}$.

except that essentially complete reabsorption of bicarbonate might be anticipated during metabolic acidosis (19)

\section{DISCUSSION}

The mechanisms by which starvation-induced hyperketonemia occurs in humans are not well defined. Under steady state conditions, when plasma ketone-body concentrations are constant, the rate of their production must equal their rate of removal. An imbalance, however slight, between these rates would result in a change in plasma concentration. Thus, an increased production or a decreased removal of the ketone bodies or both of these processes may be involved. During starvation the major mechanisms for ketone-body removal are terminal oxidation and urinary excretion.

Our data show that a rapid increase in AcAc and total ketone-body production occurred early during progressive ketosis induced by starvation. After 2-3 days of fasting, under conditions of mild to moderate ketonemia and ketonuria, AcAc and total ketone-body oxidation rates were about $98 \%$ of the production rates. The small difference between these rates, which could not be accounted for by the average urinary excretion rate of about $0.14 \mu \mathrm{mol} / \mathrm{kg} / \mathrm{min}$ (Table IV), may have been responsible for the increase in plasma ketone-body concentrations.

After 17-24 days of fasting under conditions of more severe ketonemia and ketonuria, AcAc and total ketonebody production and oxidation rates were increased further. However, no relationship between plasma concentrations and rates of production or oxidation was apparent (Fig. 3). Continued increases in plasma ketonebody concentrations in spite of a constant production rate could at least partially be explained on the basis of a limited capacity for ketone-body removal. The mean maximum total ketone-body production and oxidation rates were about $11 \mu \mathrm{mol} / \mathrm{kg} / \mathrm{min}(150 \mathrm{~g} / 24 \mathrm{~h})$ and about $9 \mu \mathrm{mol} / \mathrm{kg} / \mathrm{min}(129 \mathrm{~g} / 24 \mathrm{~h})$, respectively. Ketonuria accounted for an additional $14 \mathrm{~g} / 24 \mathrm{~h}$ (Table IV). The difference between the rate of total ketone-body production and removal is about $7 \mathrm{~g} / 24 \mathrm{~h}$.

It is important to note that the imbalance between ketone-body production and removal rates that we observed afer short and long periods of fast may be due to inherent methodological errors or limitations involved in estimating these processes. For example, other investigators have demonstrated that labeled carbon from $\left[{ }^{14} \mathrm{C}\right]$ ketone bodies is incorporated into compounds other than $\mathrm{CO}_{2}$, i.e., fat and protein $(20,21)$. Balasse and Havel (20) suggested that this process, which may be due to isotopic exchange, could result in an underestimation of ketone-body oxidation rates. A similar underestimation in our studies could account for the discrepancy we have observed. Certainly, after 24 days of fasting, blood ketone-body concentrations are reasonably constant on a day-to-day basis (22), indicating that rates of production and removal are equal.

The relationship between rates of ketone-body production or oxidation and plasma concentration that we have found in fasting obese humans is remarkably similar to that observed in rats (23), rabbits $(24)$, sheep $(3,25)$, and dogs (20). However, because of higher metabolic rates in smaller animals, absolute rates of ketone-body production and oxidation are not comparable to those in the human. It is of interest that only about one-half of the ketone-body production could be accounted for by immediate oxidation to $\mathrm{CO}_{2}$ in ketotic sheep $(3,25)$ and dogs (20) whereas in the human this fraction is considerably greater. Possible reasons for this include a

Ketone-Body Metabolism in Obese Humans 513 
somewhat larger relative brain size in humans as compared with smaller animals and the presence of a large adipose tissue mass in our obese subjects. Both brain (26) and adipose tissue $(21,27)$ have been shown to utilize ketone bodies.

The available literature contains limited information on rates of ketone-body production and utilization in humans during total starvation. With catheterization techniques in obese subjects fasted for 3-6 wk, net total ketone-body production rates of $109 \mathrm{~g} / 24 \mathrm{~h}$ and utilization rates including ketonuria of $112 \mathrm{~g} / 24 \mathrm{~h}$ have been reported (28). The values obtained in this study by an isotope tracer technique are greater. Recycling of radioactivity, assumed to be negligible (10), would have resulted in an error in the opposite direction, i.e., an underestimation of the production rate. The use of total ketone-body specific activity as a base for calculation may also have resulted in some error, but this procedure was necessary because of the lack of isotopic equilibration between AcAc and $\beta$-OHB. However, the major reason for the discrepancy is probably due to the fundamental differences in the parameters that each technique measures. Although the liver is the only organ that makes a net contribution of ketone bodies to the bloodstream, evidence has been presented that certain tissues of the human may produce and utilize ketone bodies simultaneously $(22,28-30)$. In such tissues isotope tracer techniques would detect ketone-body production and utilization not determined by direct balance methods.

The ability of renal tissue to produce and utilize ketone bodies simultaneously is well recognized $(22,30)$. The use of direct balance techniques in the fasted human has shown a large renal extraction of $\beta-\mathrm{OHB}$ and a small release of AcAc into the bloodstream (22). The results of the present study also indicate a renal production of AcAc, although the source of this ketone body cannot be established. It may arise by a de novo synthesis from precursors such as plasma FFA, amino acids, or $\beta-O H B$. Of the total AcAc produced by renal tissue, only that appearing in urine can be estimated. In our studies, this quantity is small compared to the total endogenous production.

On the basis of theoretical considerations, a maximum rate of total ketone body production in the human of about $200 \mathrm{~g} / 24 \mathrm{~h}$ has been proposed (31). Splanchnic production rates of 195 and $385 \mathrm{~g} / 24 \mathrm{~h}$ have been reported in two diabetic patients with severe ketoacidosis (32). ${ }^{2}$ The average rate observed in our subjects, about $150 \mathrm{~g} / 24 \mathrm{~h}$, is somewhat less than these values. However, there is no reason that the rate of ketogenesis during starvation should be maximal; it is more reasonable to assume the rate should be high enough to meet the

\footnotetext{
${ }^{2}$ In a third patient, total ketone-body production was 11 $\mathrm{g} / 24 \mathrm{~h}$.
}

physiologic need. During starvation, this need is reasonably large, and an important role of the ketone bodies as they contribute to caloric homeostasis has been emphasized (6). The rate of total ketone-body oxidation in our subjects was about $129 \mathrm{~g} / 24 \mathrm{~h}$. Assuming an average caloric value of $4.5 \mathrm{kcal} / \mathrm{g}$ (33), it may be calculated that the oxidation of these substrates provided about $580 \mathrm{kcal} / 24 \mathrm{~h}$ or about $32 \%$ of the basal daily caloric expenditure of $1800 \mathrm{kcal}$ (22). Rates of glucose oxidation of about $50 \mathrm{~g} / 24 \mathrm{~h}(200 \mathrm{kcal} / 24 \mathrm{~h})$ have previously been reported for obese subjects of similar body weight and duration of fast (17). The remainder of the basal metabolic expenditure, about $1000 \mathrm{kcal} / 24 \mathrm{~h}$, is undoubtedly derived from the terminal oxidation of FFA and would require about $110 \mathrm{~g} / 24 \mathrm{~h}$ of this substrate. The production of $150 \mathrm{~g} / 24 \mathrm{~h}$ of ketone bodies, about 1.5 mol, would consume an additional $96 \mathrm{~g} / 24 \mathrm{~h}$ of FFA. Thus, the rate of oxidation of FFA to ketone bodies and to $\mathrm{CO}_{2}$ and $\mathrm{H}_{2} \mathrm{O}$ is about $206 \mathrm{~g} / 24 \mathrm{~h}$ and accounts for approximately $45 \%$ of the total FFA turnover, which ranges from $450-480 \mathrm{~g} / 24 \mathrm{~h}$ in long-fasted obese subjects $(18,34)$.

\section{ACKNOWLEDGMENTS}

The authors gratefully acknowledge the technical assistance of Maureen Donohue, Anne Cedrone, Catherine Tascione, and Maria Walther.

This work was supported by NIH Research Grants AM13527 and FR-5585 and from U. S. Public Health Service Grant 5 M01 RR 349, NIH, General Clinical Research Centers Branch.

\section{REFERENCES}

1. Bates, M. W., H. A. Krebs, and D. H. Williamson. 1968. Turnover rates of ketone bodies in normal, starved, and alloxan-diabetic rats. Biochem. J. 110: 655.

2. Katz, M. L., and E. N. Bergman. 1969. Hepatic and portal metabolism of glucose, free fatty acids, and ketone bodies in the sheep. Am. J. Physiol. 216: 953.

3. Bergman, E. N., and K. Kon. 1964. Acetoacetate turnover and oxidation rates in ovine pregnancy ketosis. Am. J. Physiol. 206: 449.

4. McGarry, J. D., and D. W. Foster. 1972. Regulation of ketogenesis and clinical aspects of the ketotic state. A brief review. Metab. (Clin. Exp.). 21: 471.

5. Williamson, D. H., and R. Hems. 1970. Metabolism and function of ketone bodies. In Essays in Cell Metabolism. W. Bartley, H. L. Kornberg, and J. R. Quayle, editors. Interscience Publishers, Ltd., London. 257.

6. Krebs, H. A., D. H. Williamson, M. W. Bates, M. A. Page, and R. A. Hawkins. 1971. The role of ketone bodies in caloric homeostasis. Adv. Enzyme Regul. 9: 387.

7. Williamson, D. H., J. Mellanby, and H. A. Krebs. 1962. Enzymatic determination of $D(-)-\beta$-hydroxybuty-

\footnotetext{
${ }^{3}$ Calculated on the basis of $4 \mathrm{~mol}$ of ketone bodies produced from 1 mole FFA (as palmitate, mol wt 256).
} 
ric acid and acetoacetic acid in blood. Biochem. J. 82: 90.

8. Weichselbaum, T. E., and M. Somogyi. 1941. A method for the determination of small amounts of ketone bodies. J. Biol. Chem. 140: 5 .

9. Van Slyke, D. D. 1917. Studies of acidosis. VII. The determination of $\beta$-hydroxybutyric acid, acetoacetic acid and acetone in urine. J. Biol. Chcm. 32: 455.

10. McGarry, J. D., M. J. Guest, and D. W. Foster. 1970. Ketone body metabolism in the ketosis of starvation and alloxan diabetes. J. Biol. Chem. 245: 4382.

11. Issekutz, B., Jr., P. Paul, H. I. Miller, and W. Bortz. 1968. Oxidation of plasma FFA in lean and obese humans. Metab. (Clin. Exp.). 17: 62 .

12. Bray, G. A. 1960. A simple efficient liquid scintillator for counting aqueous solutions in a liquid scintillation counter. Anal. Biochem. 1: 279.

13. Hoffman, W. S. 1937. A rapid photoelectric method for the determination of glucose in blood and urine. J. Biol. Chem. 120: 51 (as modified by Technicon Autoanalyzer Methodology, N-26).

14. Dole, V. P., and H. Meinertz. 1960. Microdetermination of long-chain fatty acids in plasma and tissues. J. Biol. Chem. 235: 2595.

15. Steele, R., N. Altszuler, J. S. Wall, A. Dunn, and R. C. de Bodo. 1959. Influence of adrenalectomy on glucose turnover and conversion to $\mathrm{CO}_{2}$ : studies with $\mathrm{C}^{14}$ glucose in the dog. Am. J. Physiol. 196: 221.

16. Tavill, A. S., A. Craigie, and V. M. Rosenoer. 1968. The measurement of the synthetic rate of albumin in man. Clin. Sci. (Oxf.). $34: 1$.

17. Paul, P., and W. M. Bortz. 1969. Turnover and oxidation of plasma glucose in lean and obese humans. Metab. (Clin. Exp.). 18: 570.

18. Bortz, W. M., P. Paul, A. C. Haff, and W. L. Holmes. 1972. Glycerol turnover and oxidation in man. J. Clin. Invest. 51: 1537.

19. Pitts, R. F., J. L. Ayer, and W. A. Schiess. 1949. The renal regulation of acid-base balance in man. III. The reabsorption and excretion of bicarbonate. J. Clin. Invest. $28: 35$.

20. Balasse, E. O., and R. J. Havel. 1971. Evidence for an effect of insulin on the peripheral utilization of ketone bodies in dogs. J. Clin. Invest. 50: 801.

21. Soling, H. D., R. Zahlten, W. V. Reimold, and B. Willms. 1970. Utilization of ketone bodies by adipose tissue and its regulation by carbohydrate metabolism. Horm. Metab. Res. 2: 56.

22. Owen, O. E., P. Felig, A. P. Morgan, J. Wahren, and G. F. Cahill, Jr. 1969. Liver and kidney metabolism during prolonged starvation. J. Clin. Invest. 48: 574.

23. Nelson, N., I. Grayman, and I. A. Mirsky. 1941. The utilization of acetone bodies. IV. The relation between concentration and the rate of $\beta$-hydroxybutyric acid utilization by the rat. J. Biol. Chem. 140: 361 .

24. Wick, A. N., and D. R. Drury. 1941. The effect of concentration on rate of utilization of $\beta$-hydroxybutyric acid by rabbit. J. Biol. Chem. 138: 129.

25. Bergman, E. N., K. Kon, and M. L. Katz. 1963. Quantitative measurements of acetoacetate metabolism and oxidation in sheep. Am. J. Physiol. 205: 658.

26. Owen, O. E., A. P. Morgan, H. G. Kemp, J. M. Sullivan, M. G. Herrera, and G. F. Cahill, Jr. 1967. Brain metabolism during fasting. J. Clin. Invest. 46: 1589.

27. Hanson, R. W., and Z. Z. Ziporin. 1966. Factors influencing the utilization of ketone bodies by mouse adipose tissue. J. Lipid Res. 7: 56.

28. Owen, O. E., and G. A. Reichard, Jr. 1971. Human forearm metabolism during progressive starvation. $J$. Clin. Invest. 50: 1536.

29. Hagenfeldt, L., and J. Wahren. 1968. Human forearm muscle metabolism during exercise. III. Uptake, release, and oxidation of $\beta$-hydroxybutyrate and observations on the $\beta$-hydroxybutyrate/acetoacetate ratio. Scand. J. Clin. Lab. Invest. 21: 314.

30. Weidemann, M. J., and H. A. Krebs. 1969. The fuel of respiration of rat kidney cortex. Biochem. J. 112: 149.

31. Flatt, J. P. 1972. On the maximum possible rate of ketogenesis. Diabetes. 21: 50 .

32. Bondy, P. K., W. L. Bloom, V. S. Whitner, and B. W. Farrar. 1949. Studies on the role of the liver in human carbohydrate metabolism by the venous catheter technic. II. Patients with diabetic ketosis, before and after the administration of insulin. J. Clin. Invest. 28: 1126.

33. Buskirk, E. R. 1966. Whole body gas exchange. In Proceedings of a Conference on Energy Metabolism and Body Fuel Utilization. Alfred P. Morgan, editor. Harvard University Press, Cambridge, Mass. 153.

34. Owen, O. E., and G. A. Reichard, Jr. 1971. Fuels consumed by man: the interplay between carbohydrates and fatty acids. Prog. Biochem. Pharmacol. 6: 177. 